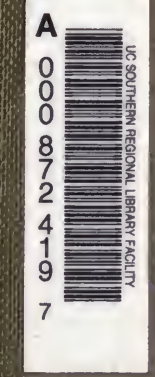

University of Californis Southern Regional Library Facility 

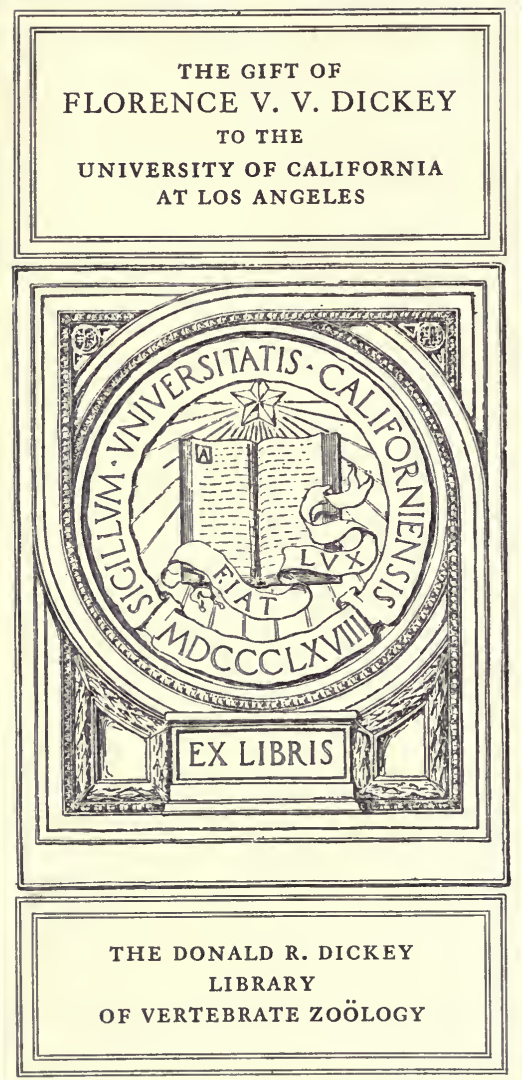


\section{LIST OF BIRDS}

In vicinity of Fishkill on-Hudson. N. Y.

BY WINFRID A. STEARNS.

During a stay of ten months in this place I have carefully studied the birds of the region; besides several small collections which I have seen, I have derived information from every available source in order to make the list as complete as possible. Endeavoring to class all birds on the basis of : Abundant, common, rather common, - not rare, rather rare, rare, I have been obliged to call the Robin, Song Sparrow, and one or two others, very abundant. The word regular signifies a spiing and autumn migrant and summer resident, breeding. The star (*) indicates that I am indebted to my friend Mr. Peter de Nottbeck for the information, either personally, or from specimens in his collection; and the dagger ( $\dagger$ ) to Mr. John Lynch, of Fishkill. I have endeavored throughout to give only what I know, and not to theorize, hence the apparent imperfectness of the list.

Turdus meratorius, Robin. - Very abundant, regular. A few remain during winter in sheltered places on the mountains, feeding on the cedar berries. 
Turdus musteurnts, Wood Thrush. Common, almost abundant, regular, very tame, and sing in the trees of door yards, arrives after the Hermit Thrush, but breeds in the woodlands.

Turdus Pallasi, Hermit Thrush.--Common, apparently regular. I have found them so late in fall and early in spring that I think they often remain during winter; prefers swamps in the highlands as well as lowlands.

Turdus swainsoni, and Turdus fuscescens were not detected at all. Mimus polyglottus, Mocking bird, has been reported from here several times, but I as yet have no positive evidence of its occurrence.

Mimus carolinensis, Cat bird.-Common, regular, prefers the lowlands.

HaRPORHYNCHUS RUFU, Brown Thrush. -Rather common, regular, prefers highlands.

Sialia sialis, Blue Bird.-Abundant, regular, a few remain during winter in sheltered places on the mountain side.

Regulus calendula, Ruby crowned Kinglet.-Not rare, during that part of winter that approaches fall and again spring, among evergreens.

Regulus satrapa, Golden-crested Kinglet.-Common, except in summer, in evergreens and almost everywhere, a tame bird and very curious, though sly.

Lophophanes bicolor, Tufted Titmouse, and Parus hudsonicus, Hudsonian Chickadee, were not found, though carefully sought after. 


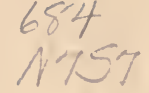

Parus atricapiluus, Black-cap Chickadee.-Common, at times abundant. I did not find it breeding, but think it must do so ; fall, winter, and spring.

Sirta carournensis, 'White bellied Nuthatch.-Common in spring, fall and winter. $I$ have found them in summer about a very small hole in a living tree, where $I$ am informed that they have bred and doubtless do still breed.

Sitta canadensis, Red bellied Nuthatch, not observed at all anywhere.

Certhia famiutaris, Brown Creeper.Rather rare at any time, irregular. I have shot it once or twice.

Troglodxtes cedon, House Wren. Common, regular ; arrives early in spring and builds about houses, very tame and familiar.

ANORTHURA TROGLODYTES $v$ ar HYEMALIS, Winter Wren.-April 2d, with snow yet on the ground, I shot a specimen between two mountain slopes in a gorge of rocks, apparently a young one. I have seen others and judge it to be a winter visitor.

Telmatodytes palustris, Long billed Marsh Wren.-If anything, not rare, regular, breeding in the marsh of Denning's Point, and perhaps other places along the river. June $2 d$, I found a nest with 5 eggs, another completed fresh, but empty, and another just begun, (the nest is begun from the outside and built inwards.) The bird arrives late as far as $I$ can judge from what I have seen.

Cistothorus stellaris, Short billed Marsh Wren, was not seen at all. 
Mnotilta varia, Black and White Creeper.-Common as a migrant, rather common as a resident. I have several times found full and partially fledged young, and once a nest with four very young birds, at Orange Lake, six miles from Newburgh, right across the river.

HeLmTtherds vermivorus, Worm eating Warbler.*-A specimen is before me taken on one of the mountains in July, 1877. It is evidently an adult, but I cannot tell whether a male or female. I saw two birds June 19 , in a rocky part of the mountain, that came so near that I could plainly see markings upon the head, and that the body was brownish, with no white upon the breast. I thought then, and do now, that they were worm eating warblers; possibly they breed here.

Dendreca astiva, Summer Warbler.Common, regular, from early spring to late fall.

Dendreca virens, Black throated Green Warbler.-Common, even at times abundant, from early spring (not known to breed) to late fall.

Dendreca cerrolescens, ${ }^{*}$ Black throated Blue Warbler.-Several specimens taken in migrations, (May.)

Dendreca coronata, Yellow rumped Warbler.-Abundant, high and low, in tall trees and low shrubbery, migrant. I do not know of its breeding, but it remained here a greater part of the last winter (1880), and were quite tame.

Dendrega blackbURnie, Blackburnian Warbler.*-Rather rare, I think migrant. A specimen was taken in May. 
Dendreca Pennsylvanica, Chestnut sided Warbler. - Not rare, perhaps rather common.

Dendreca palamarum, Yellow red poll Warbler.-I obtained a specimen April 27 th, and I think saw others, probably not rare.

Sicrus aUricapillus, Golden crowned Thrush.-Abundant in woods and on mountain sides, regular, arriving early, remaining late.

Sidrus novaboracensis, Water Thrush. *-Though I have seen it taken here, I do not think it is as common as the next.

Siurus ludoviciands, Long billed $W a$ ter Thrush. -Of which I have seen several pair in different places, always in ravines by rocky running water. I have often lain still and had their curiosity prompt them to approach within a few yards of me, remaining about for some time, but always active. I am convinced that they probably breed, and believe them to be not rare and regular.

Geothlypis trichas, Maryland Yellow Throat.-Rather common, regular; along deserted wood roads at foot of mountains.

ICTERIA virens, Yellow breasted Chat.* -On the authority of Mr. de Nottbeck, who has a skin of one in his collection, it is not rare in the brush at the foot of the mountains. I have not seen it alive here.

Myiodioctes mitratus, Hoóded flycatching Warbler.-I have several specimens of this bird, apparently adult males; spring.

Pyranga rubra, Scarlet Tanager.*Rather common, or not rare, undoubtedly regular. 
Setophaga roticiula, Redstart.-One of our well known birds and songsters in slightly marshy tall growths. I feel sure it breeds, from the lateness I have found it, but cannot say positively.

Pyranga Astiva, Summer Redbird.A bird "entirely scarlet" has been reported to me. I have no doubt it occurs rarely.

Hirundo horreorum, Barn Swallow.Common, regular.

TACHYCINETA BICOLOR, White bellied Swallow.-Rather common in spite of the belief of some that it is rare or wanting, as late as June 2d all about Denning's Point. I cannot say for certain either that it breeds or is regular.

Petrochemdon Lunifrons, Cliff or Eave Swallow.-Not rare, in spring.

Cotyue riparia, Bank Swallow.-Common, regular.

Progne purpurea. - On the authority of Mr. Benj. Strong of the Dutchess Hat Works.

AMpelis Cedrorum, Cedar Bird.-Common, regular. Abundant in flocks in spring and fall, several flocks remained here all last winter.

Vireo outvaceus, Red eyed Vireo.-I think I have seen this hopping among the branches of the apple trees.

Vireo Giuvus, Warbling Vireo.*-Not rare, probably regular from its late occurrence.

VIreo sourtarius, Blue headed solitary Vireo.*-One specimen obtained.

Vireo flavifrons and Vireo novaboracensis.-Not seen. 
Collurio Borealis, Great Northern Shrike.*-Occasionally, "December, 1874," $I$ have seen it since flying.

Pinicola endcheator, Pine Grosbeak. -I have seen a specimen taken here, no date was attached.

Corpodacus pUrpureus, Purple Finch. -Common, regular, possibly winter, as I have seen them late in fall and early in spring.

Loxia CURvirostra, var Americana, Common Red Cross bill.*-One specimen from this place dated "October, 1877," and one labeled "St. Regis Lake, Adirondack Wilderness, adult, October, (late in the month,) 1877," is all the evidence that I have seen of this bird here, though it doubtless occurs frequently and in winter.

None of Egiothus were seen, though they have been heard of lately as being here in former years ; nor has Chrysomitris pinus been taken.

Chrysomitris tristis, Goldfinch.-Abundant, regular. A great many passed the winter (1880) here.

Passerdulus savanna, Savanna Sparrow.-Rather common, though I don't know as it breeds, in spring and fall.

- Pooecetes gramineus, Bay winged Bunting, Grass Finch.-Not rare, so far as I have seen, only in small flocks in fields near low brush wood, spring and fall.

Melospiza Palustris, Swamp Sparrow. -A specimen shot almost to pieces answered the description of this bird as near as it did anything; it was shot in a swamp.

Spizelita montrcola, Tree Sparrow.Common in migrations, and late in fall. 
Melospiza melodia, Song Sparrow.Very abundant, regular, a few pass the winter.

Junco hrexalis, Snow Bird.-Abundant in spring, fall, and late fall and early spring if not throughout winter in the monntain retreats.

Sptzelta socialis, Chipping Sparrow. Abundant, regular, late in fall, early in spring.

Spizelua pusilut, Field Sparrow.Common, regular, found also in woods at base of mountains, where its song often deceives you for that of certain of the warblers.

ZONOTRICHIA ALBICOLLIS, White throated Sparrow. - Perhaps the most abundant species during migrations, prefers brush wood. I have not found them breeding, nor in winter, though very late in the fall.

Zonotrichia lencophrys. - I am certain I have seen one or two times.

Passérella iliaca, Fox sparrow.Abundant in migrations, as early as March 19 , and very late in the fall.

Goniaphea ludovictana, Rose breasted Grosbeak.*-“Adult male, June, 1875."

Cyanospiza cyanea, Indigo Bird. - Rather common, or at least not rare; perhaps breeds, as I have shot it in early June.

Cardinalis virginianus has not been seen or heard of.

Pipilo erythrophthalmus.-Common, regular, in highland and lowland and thicket, sings best in the evening, a rather late . arrival.

Agelaidus phenniceus. - Abundant, regular except in winter, occurs late in fall. 
DOLICHONYx ORYZIVORUs, Bobolink.Common, rather local, regular, except in winter.

Molothrus pecoris, Cowbird.-Common in flocks in migrations, resident.

Sturnella Magna, Meadow Lark.Abundant, regular, occasionally found in flocks at foot of mountain in winter. (I find that they have remained here in winter before.-E. A. Mearns.)

Icterius spurius, Orchard Oriole, occurs, but I have not yet taken it, though I am positive $I$ have seen it.

ICterus BaLTIMORE, Baltimore Oriole. -Abundant, regular, a late arrival in the spring.

Scolecophagus ferrugineus ought to have but has not been seen.

Quiscalus PUlipureus, Crow Blackbird. -Common, regular, arrives early and departs late.

Corvus americands, Common Crow.Abundant, regular, a few remain during winter.

Cyanurus cristatus, Blue Jay.-Abundant, regular, winters here.

Perisoreus canadensis, Canada Jay.* -Adirondack mountains.

Trrannus caroutinensis, Kingbird.Abundant, regular, arrives late in spring.

Myiarchus crinitus, Great crested Fly catcher.-Not rare, perhaps even rather common in spring; I have found it in the mountains and on the lake shore of the lowlands of Orange Lake, and heard it often late in the spring; I suppose it to breed, but cannot prove it. 
Sayornis fuscus, Pewee, Phoebe.-Common, regular, arrives early.

Contopns borealis and C. virens and others not seen at all, probably common.

Empidonax minimus, Least Fly catcher.

ANTROSTONUS VOCLFEROUS, Whip-poorwill.-Rather common, regular, though hard to obtain from its nocturnal habits ; April 30, and even earlier.

Chordemes virginiands, Nighthawk.Common, regular. This bird is also hard to obtain from its retirement in daylight.

Chatura pelagica, Chimney Swift.Abundant, regular, arrives late and departs rather early.

CeRYue alcyon, Kingfisher. - Rather common, regular. I have seen them very late in fall and in winter.

I have seen one or the other of the Coceyzus, or cuckoos, flying, but could not distinguish which species it was.

Hylotomus pileatus, Pileated Woodpecker.†-Greene county.

Picus viulosus, Hairy Woodpecker.Not rare, Oct. 23, one specimen, resident throughout the year, and regular.

Picus PUbescens, Downy Toodpecker.Common, resident throughout the year, and regular.

Sphyrapicus varios, Yellow bellied Woodpecker.-I shot one specimen, April 19 , in the yard as he was tapping upon a small pine tree.

Metanerpes erythrocephalus, Redheaded Woodpecker.*--An immature specimen, with no date, appears in my friend's collection from this place. 
Colaptes auratus, Golden winged Woodpecker.-Common, regular. I have seen it in late fall and early spring, but do not know as it winters.

TrochILUs CoLUBRIs, Ruby throated Humming bird. - Several, only seen.

Bubo virginianus, Great Horned Owl.I feel sure that I have noticed this bird somewhere, but cannot now tell where.

Nyctea nivea, Snowy Owl.†-One specimen shot in Newburgh.

Scops asio, Mottled Owl.-Rather common, probably regular and throughout the year.

Neither of the Eared Owls yet observed.

Syrniom nebulosum, Barred Owl.*Not rare, probably regular, often found in the swamps.

Circus Cyaneus, Marsh Hawk:-Rather common, regular.

ACCIPITER FUscus, Sharpshinned Hawk. *-Not rare, lowlands, several specimens examined.

ACCIPITER COOPERI, Cooper's Hawk.*Not rare, lowlands, several specimens.

Falco sparverius, Sparrow Hawk.-I have seen it flying several times.

Buteo borealis, Red tailed Hawk.Rather rare, lowlands, probably regular.

Buteo uineatus. - May be rather less rare than the last; neither appear to be common.

Pandion haliatus, Fish Hawk.*-Rather common, spring and perhaps fall.

Zenadura carolinesis, Carolina Dove. - Rather rare, regular, generally found in pairs. 
Haliztus leucocephalus, Bald Eagle.* - Rather common in spring when the ice of the river breaks up, possibly a pair occasionally breed on the cliffs of Storm King on the opposite side of the river; the old settlers of the place at least affirm it.

Ectopistes maratorids, "ild Pigeon. Not rare in migrations, but I do not know of their breeding, though they probably do occasionally.

Bonasa umberuus, Ruffed Grouse, Partridge.-Now rather rare, formerly nearly common, having been killed off by the wild cats on the mountains and the hunters on the lowlands ; regular, and winters.

OrTyx virginiands, Quail._-Not rare at Orange Lake, the only place I found them, probably regular, as I found them June 10, apparently mated.

Agiamisis vocifenous, Killdeer Plover. †-Rather rare, occasional.

Galminago wilsoni, Snipe.†-Not rare, fall.

Philohela minor, Woodcock.-Not rare, a few may breed, but I think the most do not.

Totanus melanoleucus, Greater Telltale.*-A single specimen, not labeled, was taken from this region.

Tringoides macularius, Spotted Sandpiper.-Common, regular.

Ardea herodias, Great Blue Heron.*Not rare, fall, all along the river.

Ardea virescens, Green Heron.-Rather common, apparently regular.

Galuinula galeata, Florida Gallinule.-Apparently rare, a single specimen was shot here, but the date is not given. 
Botaurus uentiginosus, Bittern. $\dagger-$ Occasional.

Porzana Carolina, Carolina Rail.*-Not rare, migrations, October.

Fulica a Mericana, Coot.*-Several specimens have been taken, one as early as April.

Branta bernicla, Brant Goose. $\dagger$-Not rare, fall.

Brantv Canadensis, Canada Goose.†Not rare, fall.

Anas boschas, Mallard. $\dagger$ - Not rare, fall.

Anas obscura, Dusky or Black Duck. $\dagger$ -Rather common, fall. Mr. Lynch speaks of there being what he calls a second kind which often flies with this bird, and calls it Norwegian Black Duck. I cannot positively identify it.

Dafila acuta, Pintail.*-Rare. A single specimen, male in full plumage; had not been seen before by many of the old hunters here who had seen it. Date not given.

Mareca americana, Widgeon.†-Quite common, in flocks of 15 or 20 ; they are acute divers, and like several others, take wing immediately upon appearing at the surface.

QUerquedula carolinensis, Gieen winged Teal.†-Rather common, but less so than they used to be, in small flocks in early fall.

Querquedula piscors, Blue winged Teal. + -Not rare in early fall in family broods.

Mergus Serratus, Red breasted Meganser. ${ }^{*}$-Not rare in migrations. 
AIx sponsa, Wood or Summer Duck.†Not rare, breed occasionally at Brinckerhoffville Pond.

Fuligula marila, Greater Blackhead. $\dagger$ -Rather common. Mr. Lynch mentions two species, the other smaller than this one and is probably $\mathrm{F}$. affinis.

Fuligula valissneria, Canvas-back Duck. †-Rather rare, a few are sten occasionally.

Fuligula Ferina, Redhead.*-Rather rare. A single specimen was obtained, date not given.

A duck named "Bucephala americana, March, full plumaged male,"* with the white loral spot touching the bill.

Bucephala islandica, probably occurs.

A specimen, evidently female Bucephala, shot Dec. 24, no white on head and eye red.

Hareuda glactalis, Long tailed Duck. -Rather common. I have seen quite a number in full plumage.

CEdemia americana, American Black Seoter.†-Rather rare, but occasionally taken.

OEdemia perspicilulata, Surf Duck.†Rather rare, but occasional.

CEdema Fusca, Velvet Scoter.*-Rather rare. A single fine male, date not given, was obtained.

Erismatura rubida, Ruddy Duck.Common in migrations, flocks or singly.

Larus phimadelphia, Bonaparte's Gull. *-One specimen, shot in autumn of 1871 , in immature plumage. 
Larus argentatus, Herring Gull.Abundant, spring, fall, and mild winters when the river is not frozen, in nearly all its different plumages.

Colymbus torquatus, Great Northern Diver.-Rather common or not rare, several specimens.

Colymbus septentrionalis, Red throated Diver.*-A specimen in Mr. de Nottbeck's collection, (Bull. Nutt. Orn. Club, Vol. III, p. 146,) in young immature plumage; and a second specimen taken in the river some years later, are interesting records, and new to science.

Podiceps connutus, Horned Grebe.-A young specimen had the whole under parts silvery white, sides slightly ashy brown, all the secondaries seven-eighths of an inch white tipped. No lengthened feathers.

Podicymbes podiceps, Piedbilled Grebe. -Not rare, spring and fall, several specimens, and in full and immature plumage. 
University of Callfornia

SOUTHERN REGIONAL LIBRARY FACILITY

405 Hilgard Avenue, Los Angeles, CA 90024-1388

Return this material to the library

from which it was borrowed.

unear IH?

FEB 17 Bas 
QL Stoarns -

684 List of birds in

N7S7 vicinity of

Fishkill on-HudSon, N.Y.

QL

684

N7S7
UC SOUTHERN AEGIONAL LIBRARY FACIUTY 
